\title{
The Governance of the Sociogenic Climate Change: Perspectives and Challenges
}

\author{
DIMITRA KOUMPAROU \\ Hellenic Open University, GREECE
}

\begin{abstract}
The Anthropocene is defined as the most recent geologic time period of earth, in which human activities influence the atmospheric, geologic, hydrologic, biospheric and other earth system processes. This term encompasses two different but equally important concepts: Nature and the Human. The dominance of the natural and physical sciences in the subject of climate change is historically documented. In contrast, the involvement of social sciences and the interdisciplinary dialogue developed over the last two decades and were launched by economic analysis. Social sciences also articulate the idea that the edifice of modern society is under pressure from climate change. The emerging question is not how human beings influence the earth systems but how the whole social system (economy, policy, culture, religion, gender, ethnicities, ethics, and technology) impacts them. Systems, biophysical and social, play a crucial role in the configuration of climate change. This work endeavours to show that the modern tragedy of the commons creates a climate for change, that is, it offers the opportunity to turn climate change by transforming society into the new post-carbon society.
\end{abstract}

\section{Keywords}

climate change, society, science, globalization, commons, governance

\section{Introduction}

The social dimension of climate change is inherent in the term 'Anthropocene', successor of the Holocene (the 'wholly new' era). The term 'Anthropocene' is defined by other principles and criteria, above and beyond geological, biological and meteorological criteria, observations and data. It bears political and economic, technological and moral dimensions; it bears the social element. As Wissenburg (2016) underlines, "it denotes an artificial break in geological and climate history". Beyond all, this era recognises humans' sovereignty over nature. The Anthropocene denotes that 'Anthropos', from the ancient Greek word 'á $\nu \rho \omega \pi \varsigma^{\prime}$ ', can, according to the Greek philosopher Plato, contemplate and analyse what they are seeing and facing. Anthropos as a political being, according to another Greek philosopher, Aristotle, develops a network of relationships with other individuals and a network of relationships with the other elements (living or not) of the Earth.

Dibley (2012) attributes the following seven theses to Anthropocene: (1) the name that embraces human involvement in the planet, (2) a radical new turn, (3) a state that interrogates materiality and the consumerism, (4) a concept that brings to light the disconnect between nature and society, (5) a term that dictates a new nexus between Society and Nature, (6) a view that reclaims an 
integrated approach to the Earth: social-biophysical, and (7) a symbol of the new conceptualisation of the term progress and growth.

Today, 'Anthropos' as a social and political being is concerned about the future of the Earth and has to contemplate solutions for the environmental problems caused by its actions and the dominant economic model. The socionatural or natural-social highly complex system that has been established for centuries now demands fundamental transformations (de Molina and Toledo 2014). Science as a whole - natural and social sciences - works on analysing the present situation in a comprehensive way with the purpose of confronting the challenges of the immediate and distant future. The above commitment of total science calls for full and unconditional compliance with two provisions: the development of a comprehensive and interdisciplinary conceptual framework that coordinates research developed by the studying - both analytically and synthetically - of the relations between Society and Nature; and the subsequent construction of a functional and meaningful analysis of these relations, taking into the account the dimensions of time and space, past and present, local and global.

The juxtaposition between nature and human being, society and culture, introduced the cognitive framing of understanding the whole world and humans' position in it. For Berkes and Folke (1998), the concept of socialecological systems reflects that nature and society are co-dependent and constantly co-evolving. Climate change as it is stated and communicated has pervasive impacts on all parts of the social and natural systems. And as Fauchald et al. (2017) report, climate change, like globalisation, has impacts not only at a broad level but on a local level too. New challenges and questions arise for both the natural and the social sciences, and the "Tragedy of the Commons' is coming back in a more severe and threatening way. Nevertheless, we live in an era where the human-nature relationship is determined by the neoliberal policy, ethos and economy. The so far unpaid work of nature, as Moore (2014) argues, is in the orbit of change, and climate change might be the high price that human society must pay today and tomorrow.

In addition, societies have to consider how to act and respond to the threats, risks and uncertainties created by them and imposed on themselves and on others (Hayward 2012). There is an ethical dimension in global climate change, and towards humans, contemporary and future, but also to the other living organisms, as Jamieson (2007) notes. Given this testimonial, ethics reflect what type of niche human beings consider they should have in the Earth system, the actions they should exercise, and in which way and by what tools. The term 'human', beyond individualism, bears the social dimension 
and the complex web of relations in the realms of policy, economy, religion, law, power, gender, justice, and democracy, among others.

Climate change could be seen as the crisis of modern civilisation. Industrial and market growth bring further inequality and for two centuries have caused migratory movements that are still under way. The mode of political organisation of the 19th and 20th centuries seems to be over. Under globalisation, states seem to lose their sovereignty by the market and in few cases, by local communities. An illustrative example is human rights. They challenge statehood and its function, as nation entities have no power to curtail or to prejudice them (Bakker 2007). Under the neo-liberal context, human rights presuppose that people are atomised, autonomous, selfgoverned, self-interest maximisers seeking happiness and well-being, independently. In this construction of human rights there is no place for a joint effort or expectation for the establishment of co-operative organisational modes as a social group or a community (Kottak 1999; Koumparou 2017).

This paper speaks about the need for the science of climate change to be a unity of the sciences. Under climate change, social and territorial units become laboratories of experiments (Lowe et al. 2013). Therefore, sociotechnological and socio-ecological adaptation needs multidisciplinarity to lead us to the new era of the green or post-carbon or other society. This new setting presupposes the breaking of resource dependence (Urry 2011) and a new way of thinking and behaviour.

Using the example of bottled water as emblematic of the neo-liberal thought of the commodification of every element of life, this paper presents how the consumerism of western societies has transformed our needs to some kind of personal identity, where water is not considered as a common need of all living organisms in our planet. This type of dominant social and economic prioritisation has direct impacts on environmental behaviours that are accepted as rational by individuals and societies, although they are economic, environmental and socially unreasonable and unsustainable. And the West is continuing to live in this way, knowing that climate change and other forms of environmental degradation are a threat for its own life as well. As Robbins (2005) notes, our society does not consider consumption as an environmental problem, as this perception urges massive cultural renovation, which might provoke a severe economic disorder. The tragedy of the commons has a global character now, provoking social scientists to give urgent answers. Climate change is the result of the personal and social life and behaviour of western citizens.

In this work it is stated that climate change is a societal problem, according to Durkheim's argument of the social fact that "the determining cause of a social fact -climate change in our case - must be sought among the antecedent social facts and not among the states of the individual consciousness". 
Climate change is structured on the division of Human and Nature, the capitalistic spectrum of interactions and organisations, with the inherent potential to create new environmental modernisation, post-modernist society, as Mol (2001) named it, or post-carbon society, according to Urry (2011).

\section{Climate change and its societal character}

Looking back to the past two centuries, we encounter the first reference to climate change due to human intervention. Von Storch and Stehr (2006) inform us that in 1890 the geographer Eduard Bruckner referred to anthropogenic climate change caused by deforestation as a part of agricultural expansion (human activity). He gave a description of the problem in Italy, the USA, Prussia and Russia. He focused on the impact of deforestation in climate deviations in the form of the alternation between heavy rainfall and increasing drought. He made references to political actions describing how governments address the issue of the nexus between forestation and climate. In 1896, Arrhenius (Von Storch and Stehr 2006) proposed that the global, near surface, temperature will increase because of the emission of greenhouse gasses. As a scientific conjecture it was alluring, but it was neglected because its validity was difficult to test. From then, a rich period has been underway, and Arrhenius is considered to be the father of climate change (Von Storch and Stehr 2006).

Today, society takes it for granted that the concept of the global climate change is a phenomenon that has recently been identified. In our era, global climate change is a crucial matter in public domain and dominates in public discourse and environmental, political and social agendas (Peterson and Broad 2009). In these agendas and discourses, a stock of questions concerns the division and the cooperation between social scientists and natural scientists. Until now, the role of social sciences was auxiliary in the topic of climate change. In the case of climate change, until recently the only 'societal' approach was an economic one. New questions and fundamental premises arose about the path where the imperative GDP growth of states and monied interests of selfish individuals could lead in a new re-arrangement of society, achieving sustainability and forming new types of governance and policy.

As Dryzek et al. (2003) mention, climate change is the most profound challenge ever to be confronted by society, the economy and policy. Its importance was identified in the late 80s (Urry 2015). Climate, science, politics and business are stuck in a vicious cycle. After the COPE 21 conference in Paris, Rubin (2016) notes that the power of the USA makes it one of the most significant forces of the global governance of climate change. Until recently, climate change was considered to be a national security issue. In a destructive way, the USA was rolling back climate policies because 
energy generates more revenue than any other industry; the most obvious reason for the USA's rejection and denial of climate change is industry. However, the USA focus is also on security in its military and law enforcement dimension, ignoring the cataclysmic flooding that threatens public health and security. Meanwhile, scientists look warily toward melting glaciers in Alaska, waters lapping the Gulf Coast, and drought and famine in Somalia ${ }^{1}$ and Yemen, where the USA has deployed drones and troops (The Intercept 2017). At the other side of the Atlantic Ocean, European Union calls China - one of the two biggest producers of climate-warming greenhouse in the world - to show joint leadership on climate change (Reuters 2017).

Despite the great concern about climate change, about the atmosphere and what is going to happen to our planet, there is an 'odd' public reaction. Throughout recent history, social movements and activists have engaged in critical social and environmental problems. The privatisation of water and deforestation, among other problems of the socio-ecological realm, have sparked protests, and sometimes violent conflicts take place. However, this is not the case with climate change.

Although studying more carefully the social movements concerning the climate change a crucial shift is developed. Tradionally, activists try to prompt and motivate the society, claiming the establishment of new norms, through political procedures. A number of scholars have identified that social movements more and more often impact organisations focused on certain business activities rather than on governances. This shift is described as 'private politics' and it is defined as "situations of conflict and their resolution, without resilience on the law or government" (Reid and Toffel 2009; Baron 2003). This two-pronged approach (public and private politics) according to den Hond and de Baker (2007) transforms the 'institutional fields', challenging the legitimacy of firms and pushing them to take social movement seriously and leading them to a new set of practices, norms and beliefs. Firms threatened by social movements reconsider their technical, legal and market standards, their institutional filed that govern their behaviour (Reid and Toffel 2009).

Under the pressure of greening, which is imposed both by the state (laws and regulations) and by society (NGOs and Social Movements) the environmental behaviour of the business sector is the new battleground for competitive advantages (Galbreath 2010; Lash and Wellington 2007). Aggarwal and Dow (2015) conclude that the market is beginning to punish companies that show total disregard for the environment with their emissions and their wastes, while at the same time rewarding firms that take action to reduce their environmental impacts. Furthermore, Sullivan and Gouldson (2017) note

\footnotetext{
${ }^{1}$ https://www.reuters.com/article/us-un-famine-idUSKBN1612QB
} 
that it is unclear to what extent this pressure can force companies to become more environmentally friendly.

Slater (2007) notes that firms targeted by climate change activists revise their energy management practices and take action to reduce their emissions. Corporate governance mechanisms then are enforced. It has been reported that investors want firm boards to deal with the risks and opportunities that climate change presents. Institutional investors are concerned about board members and their way of better taking into account climate change faced by their companies, and how this sets out the company's strategic orientation. Economy, climate, society are amalgamated causing a new system of power and governance.

What makes climate change a unique problem for the socio-environmental system is its ontological status. Climate change is not a subject of physical or social studies. According to Brace and Geoghegan (2011), it is a unique category of knowledge. As Leyson (2014) states, it is a metaphysical and semiotic problem; it is a statistical construction beyond a social one. Naustdalslid (2011) mentions that climate change is a scientific construction because only scientists identify it by their research and subsequently disseminate this information to policy makers, and through the cultural industries, to the public sphere. However, this scientific knowledge gives no certain answers to this critical subject, which is somehow invisible to society. More importantly, society draws its attention to extremes, whether facts or images, mistaking them as climate change. Society gets a filtered image of climate change (Von Storch and Stehr 2006).

The dimension of time is a critical factor in the construction and comprehension of climate change by the public. Climate change operates on a time scale that is beyond the experience of today or everyday life. This consideration can explain why in medieval times, extreme weather conditions were a punishment of God for parishes that were not following God's word in their lives (Von Storch and Stehr 2006).

This scale is much longer than a typical societal affair (Steffen 2015). Not only because of this but also for the equity issue, among others, climate change is "a truly complex and diabolic policy problem", according to Steffen (2015). The writer argues that climate change is a multi-faceted social problem, or at least a sociogenic problem.

Social scientists and, recently, environmental scientists argue that there are no clear boundaries between culture and environment, and it could be argued that materiality is underlying the climate change process. As Wilk (2017) points out, "without consumer culture, there is no Environmental Crisis" and therefore no threat of climate change either. 
Although there are many different consumer cultures that vary not only from place to place but also from social group to social group in the same territory, the core idea of the consumer culture is the 'need'. In the western world, 'need' is enmeshed with the concept of pleasure, delight or convenience, in contrast to the rest of the world. For example, Urry (2015) studying the nexus between society and climate change, uses the automobile culture as an emblem of developed, fossil-fuel dependent societies. Bottled water in this work is considered the emblem of consumerism. Bottled water depicts how consumerism is the chargeable event of the environmental crisis in general and contributes to the social phenomenon of climate change (Gleick 2004; Trentmann and Taylor 2005; Wilk 2006, 2011; Koumparou and Golfinopoulos 2015; Koumparou 2017).

Bottled water embodies all the characteristics of a manufactured product. For neo-liberal economy, water is a foodstuff and should have a market value. Savenije (2002) notes that water is "not an ordinary economic good". For Crook et al. (2009), bottled water is not only an industrial product but also has social dimensions and may even be perceived as a social phenomenon (Ferrier 2001) or as a total social fact, as Koumparou (2017) states.

Modern magic, advertisement, together with the trend of people to be illustrious, transformed water to something more vigorous than a necessity. Water is packaged by an industry-based, that is fossil-fuel based, economy, and is chosen, under transformation through a certain label, by the consumers to highlight and to communicate to others their high social status. Western citizens go out of their houses, in which there is a tap with clean, safe and cheap water, and go hunting in market places to purchase the different magic water, which will offer them superficial characteristics such as youth and beauty; it will make them feel safer and healthier, offering the convenience of the bottle. Western citizens buy water in very high values, sometimes equal or more than fuel, which shares the same or sometimes worse quality standards than tap water (Doria 2006, 2010). Buying water at a much higher price than what is available already on tap is not only an economic unreasonableness. Most importantly, it is also an environmental absurdity (Johnson et al. 2001; Gleick 2004; Koumparou and Golfinopoulos 2015; Koumparou 2017).

The production of the industrialised product of bottled water is based on oil and water. On average, $60 \%-70 \%$ of the water used fill up the bottles. The rest is wasted. The manufacturing of bottles also requires energy consumption. Energy is needed not only for manufacturing plastic bottles but also for the preparation of the water for bottling. It is also used in water treatments to clean, fill, seal and label bottles, just like transportation, which contributes to gas emissions into the atmosphere. The transportation of bottled water to stores by road, rail, or ship, has an additional environmental impact, with air 
shipments being the most intensive mode of transportation (Pacific Institute 2007, Koumparou 2017). It is known that transport is the major source of greenhouse gas emissions, which in turn contributes to climate change. The disposal of plastic bottles is also a source of pollution with long-lasting impact. Tons of plastic waste are accumulated. Only a little part of it is recycled. The rest ends up in landfills or incinerators, contributing again to the emission of greenhouse gases or socio-economic gases, as Barr (2011) characterised them.

The example of bottled water shows the system of thinking and the unreasonableness of our environmental behavior; it also shows how consumerism creates a new system that is "fashionable and faddish, that wins hearts and minds that is better and more fun" paralleling with Urry's (2015) phrase about the automobile system as an emblem of the rise of fossil dependent society.

Bottled water is the symbol of the success of the Western lifestyle and neoliberal economy. Water is transformed into a manufactured product, putting it in plastic bottles. The industry has transformed the undifferentiated element of water into something supernatural that offers health, safety and uniqueness to its consumers. Bottled water, furthermore, reflects 'hydroschizophrenia' - the disconnect between society and water - the achievement of the neoliberal world.

Freud (Wilk 2017) highlighted that the price of civilisation is alienation and existential anxiety, and consumer culture always searches for the illusion of wholeness. This leads to the reflection that consumerism is a mental illness, a conceptual falsehood (Wilk 2017). This argument in turn addresses inquiries regarding whether and how consumer culture can be transformed into a sustainable one, and if this is an achievable endeavour.

What is happening now will be dealt with by the future generations. However, the issues of equity do not regard only the inhabitants of our planet today but in the long-term future, as well. The environmental dilemma faced today is what kind of world we want in a future time. It is known that $20 \%$ of the human population appropriates more than $80 \%$ of the available resources for its wellbeing. If this inequality persists, then warfare is the likely future case. The problem will be even more severe as the other $80 \%$ of the world will demand a decent standard of living compared to western criterions (Wilk 2017). Equity is related not only with North and South divisions but also with poor and rich, in industrialised and non-industrialised societies. Climate change creates a climate for conflict between classes, nations, continents, ages, and genders, and ethical, political and economic systems. Additionally, the issue of equity refers to other species of life, to other non-human species. 
There is a wider need for solidarity not only between generations but also between different territories and countries, beyond nations and states, political and geographical borders and beyond humans, in all species of life.

Socially justified answers should be given to question how society should respond to climate change and why the consensus on climate change is not taken for granted. Social sciences, in collaboration with natural sciences, try to identify what is in the wrong direction, what is the right direction, who is the key player, what matters, and what should be done (Dryzek et al. 2011). The International Social Science Council (2015), for example, reflects the way that social scientists evolved in tackling climate change by seeking more sustainable equitable paths concerning global environmental change and climate change, especially. The social sciences evolved regarding climate change to promote global cooperation towards a global knowledge for a peaceful world function. They bring to the fore an array of topics, including identities, behaviours, values, ethical systems, economics, policy, rights, governance, among others.

Environmental sociology speaks about a cosmopolitan solidarity. People with different ideologies and from different countries must act and vote for a policy regarding climate change to be less tempted to give priority to their personal interests for the benefit of the planet as a whole. The "greening of societies" demands a cosmopolitan view and a transformation of behaviours, values and priorities of contemporary society. This cosmopolitan view, along with its configuration and calibration of climate change, are under investigation by social sciences (Beck 2010). The need for further theoretical inquiry, beyond the simple accounts of attitude, behaviour and transformation, is underlined by Shove (2010), who puts forward questions about social theory and climate change. Milton (2008) notes that anthropology could be the contestation of everything: science, politics, economics, morality in the search for solutions of climate change. Anthropologists mention that the challenges of climate change require an understanding of ourselves, to bring to light how people deal with famine and flood and to give answers why programmes and policies for climate change either work or fail.

Social anthropo logy, with its powerful scientific tool of ethnographic research and its integrated approach, brings to light many case studies of mitigation and adaptation to environmental changes. It highlights different definitions of risk, uncertainty, adaptation and mitigation. It speaks about social imagination through landscapes (Crate and Nuttall M. 2009; Peterson and Broad 2009). It is engaged with diverse ecologies all over the world, beyond western concepts and order. Anthropologists identify local-level adaptations through time and at the meso and regional levels (Fiske et al. 2014). Art and cultural research represent the future of our life as parts of the 
earth system. Artists create fictional words (Toivanen et al., 2017), and Szerszynski (2016) notices that science fiction contributes to speculation of our life in the social and biophysical system of the Anthropocene.

A more critical view on social discourses is currently limited to metanarratives of social sciences, as Leyson (2014) notes. If the de-carbonisation of society is a complex and difficult procedure, then the era "Anthropocene should be studied according to the social sciences" perspective not only by focusing on the damage caused by societies but also on how and what forms of social institutions and governance, what social structure, may emerge in this case (Lowe et al. 2013; Whitington 2016), and how and what systematic shifts will probably take place.

\section{Climate change, the tragedy of the commons and global governance}

Selfish behaviour threatens societies and livelihoods. However, there should be ways for nations and communities, for families and individuals, to restrict their narrow self-interest promoted by the neo-liberal ethic in favour of the global greater good and justice. One of the most widely known models of outlining environmental problems due to self-interest and incorporating the need for global governance is Garrett Hardin's 'tragedy of the commons' (Hardin 1968).

Founded by Garrett Hardin (1968), the School of the Tragedy of the Commons is an approach that focuses on the organisation and management of common pool resources or the so-called 'commons'. Many independent users have access to them and, due to the resources» embedded characteristics, the appropriation of these resources is limitless, as any effort to restrict or control the intensity and the frequency of their use is a hard endeavour. Hardin laid out the fundamental belief that rational human beings acting according to their interest and prosperity can produce reasonable collective outputs, ending in the bleak picture of the destruction of both Nature and Society. The model is based on the premise that common pool resources are doomed to be destroyed, as each user feels that his or her personal interest prevails over the collective. The tragedy of the commons is inevitable and resources will perish. Oceans and seas, forests and meadows, wildlife and fisheries, water and global atmosphere are considered as commons. Two superficial antagonistic solutions were proposed to avoid destruction, tragedy: the status of state property and the status of private property. Both presuppose a state establishment and state institutions (Koumparou 2002). The solution for Hardin was a "mutual coercion mutually agreed upon". A similar philosophy could be sensed in the field of climate policy: in the absence of a binding international regime, each country rationally raises $\mathrm{CO} 2$ emissions, for example to increase its economic performance, despite climate damage induced by gas emissions (Harman and Williams 2013). 
Hardin's consideration triggered a different approach to the problem of the commons, which reveals the nexus between societies and natural resources and the network of relationships that are being cultivated among persons, individuals who appropriate the same resource. The studies brought into view questions of the interactions between individual behaviour and social welfare, the individual and collective interest, cooperation, self-governance, information, knowledge, social and environmental justice, bottom-up strategies, management plans and strategies. It is revealed that these concepts have different implications in different social aggregations. The objectives, priorities and implementation mechanisms (power-sharing structures) of the chosen strategies describe in detail, in each case, the total view of the relation of humans to their physical space, while at the same time deeply specify the social structure and profoundly define the relationships between individuals and social groups. The optimal strategies for natural resources management are at the heart of any environmental policy. What differentiates the various plans and strategies is the specific delineation and definition given to the concept of governance. It is not an easy procedure to establish a commons governance.

Ostrom $(1977,1987,1990,1992,2009)$ and her school develop the theory of the commons, analysing the principles that should be met for the successful and sustainable function of the commons. From the analysis of the case studies about governing the commons in a robust way, in local contexts and at a broad level all over the world, it is now understood how human institutions that are designed to be adaptive, affect the resilience of nature and play a critical role in sustainability.

All this knowledge about human-nature interaction generated by the study of the commons, the last 40 years with all their tragedies and successes, create a theoretical context for the analysis and understanding of governance and institutions (Dietz et al. 2003) in small-scale systems, such as forests, fisheries, water, meadows, for effective management, protecting both resources, products and services, and humans for long or for a short period, in the west and in the east, in the north and in the south.

For large scale systems, new queries have emerged. The principles of the institutional arrangements for global commons for climate change or oceans are not known, or they have not been identified in depth yet. This does not mean that they do not exist. Forty years ago, even the principles of governance for small-scale commons were not known (Dietz et al. 2003).

The major dilemma of our planet is inherent in the core of the catchphrase "Think Globally but Act Locally". While many of the effects of climate change are global, the causes of climate change are the actions undertaken by states, markets, communities, individuals, at a much smaller scale. If earth and its inhabitants want to eliminate climate change in the long run, the day-to-day 
activities of individuals, social groups, states and markets - particularly those in the western world of consumerism - will need to change substantially. Many of those who need to change their attitudes, however, have not yet accepted that the threat posed by climate change is not theoretical; it is real. The necessity to change their action at a local level, organising their lives in a new-fangled style has not been established yet. The greening of modernity, as Beck (2010) mentions, is what we are seeking globally to overturn the climate tragedy.

As Dietsz et al. (2003) noted, "...sustained research coupled to national and international policies...can yield the scientific knowledge to design institutions..." to avoid a climate tragedy. These institutions depict how the world is and how it ought to be, and they draw the strategy to change the world and to accommodate the desired perception (Paige 2016). Dietsz et. al. (2003) prescribe three analytical principles for the governance of the global commons: a) a discourse between interested partners that presupposes information about social-environment system, b) a multilevel governance for the best adaptation, and c) a mixture of institutional types.

This approach unfolds the multiple facets of the governance of climate change. It stresses that the governance of climate change is a multi-level, multi-sector and multi-actor phenomenon. In their analysis, it is clear that the inspiration to 'act locally' is crucial for awareness, locally devised solutions that will bring the global change formed by the implementation work ( $\mathrm{O}^{\prime}$ Gorman 2010). The community-based strategy, the core of the commons together with social organisational and political mobilisation, could open new spaces for feasible action, causing structural changes, as mentioned by Navarrete et al. (2012). Climate change is a tragedy or comedy in the grandest scale.

\section{Discussion}

It is known that in the past some civilisations collapsed because of climate change, but the situation today is much different (Steffen 2015). The term 'Anthropocene' symbolises the imbalance between two systems, the social and the environment. The concept 'Anthropocene' underlines the fact that the dominant social system which has multifaceted expressions configured by policy, economy, religion, law, and governance is the crucial player. These expressions determine not only its near future but also the future of life in time. Anthropocene is the symbol of the new era for humanity and earth. Humanity as the commander of nature causes severe malfunctions and now these two systems should confront any entropy and achieve the state of balance via a broader systematic shift. This imbalance opens new uncharted roads for both the natural and the social sciences. This phobia about the unknown, for the terra incognita, is not a good service to society which 
endeavours to recognise, to diagnose, to mitigate or to adapt to nature's reactions.

Nevertheless, the belief that technology would be the deus ex machina for the natural sciences is not the case for the social sciences, unless it is not combined with a new re-arrangement of society. Issues of technology ought to be addressed, and some approaches have to been reconciled. "Deep cuts in emissions will require a diverse portfolio of policies, institutions, and technologies as well as changes in human behavior and consumption patterns" (IPCC 2014).

The term 'Anthropocene' refers to humanity as a whole, without discrimination of place, wealth, race, gender, social class, economic status. All sites and territorial units on the earth with their unique social framing and context, under globalisation, could be transformed to laboratories of adaptation or mitigation. The social sciences draw the attention to the social construct of both concepts - 'climate change' and 'territory'. Each discipline applies its own research tools and its theories, bearing in mind that Earth is one, but the world is not, as Paterson and Stripple (2007) have noted.

Today, climate change - studied from the perspective of the tragedy of the commons, in which humanity in its totality is the appropriator of the nature - requires a cosmopolitan view and a departure from the dominant perspectives of economic models and the modes of production. In this mission, speculative experimentation becomes a necessity for the sociogenic climate change (Whitington 2016). The turn to cosmopolitanism as an answer to the tragedy of climate change is a moral and political issue. New incentives for the greening of modernity, as Beck (2010) notes, should emerge.

The tragedy of the commons is not an occurrence of modern or post-modern society (O' Gorman 2010). Aristotle (4th century B.C.) in his 'Politics' noted "that which is common to the greatest number gets the least amount of care". The 'commons' has long been a key concept in environmental science, and the resources and institutions assigned to that term have been identified as core of many environmental problems (Ostrom et al. 2001). Harman and Williams (2013) discuss that issues such as sustainable development, industrial pollution, and biodiversity conservation are crucial because they depict the way that humans relate to other species on our planet, and they introduce possible risks and uncertainties that will follow us in the future.

Our imagined post-modern or post-carbon society casts a doubt on our fundamental style of life and on the modes of production. Through the passage of the time, from the age of the Renaissance until now, natural resources have been 'socialised'. The choice of needs to be met by these 'products' concerns society as a whole. This socialisation of resources, until now, seems not to have served the needs of society equally and fairly, 
provoking resource degradation or even total destruction. An establishment of a new form of resource socialisation is the new challenge for science in its totality for a sustainable present and future. The socialisation of the issue of climate change still points to issues such as poverty, food security, and water democracy that should be addressed under this process.

\section{References}

Aggarwal, Raj and Dow, Sandra (2012) Corporate governance and business strategies for climate change and environmental mitigation. The European Journal of Finance, 18(3-4), pp. 311-331.

Bakker, Karen (2007) The 'Commons' versus the 'Commodity': Alterglobalization, Anti-privatisation and the Human Right to Water in the Global South. Antipode, 39(3), pp. 430-455.

Baron, P. David (2003) Private politics. Journal of Economics \& Management Strategy, 12(1), pp. 31-66.

Barr, Steward (2011) Climate forums: virtual discourses on climate change and the sustainable lifestyle. Area, 43(1), pp.14-22.

Beck, Ulrich (2010) Climate for Change, or How to Create a Green Modernity? Theory, Culture E Society 27(2-3), pp. 254-266.

Berkes, Fikret and Folke, Carl (1998) Linking Social and Ecological Systems for Resilience and Sustainability. In: Berkes F and Folke C (eds) Linking Social and Ecological Systems: Management Practices and Social Mechanisms for Building Resilience. Cambridge: Cambridge University Press, 13-20

Brace, Catherine and Geoghegan, Hilary (2011) Human geographies of climate change: Landscape, temporality, and knowledges. Progress in Human Geography 35(3), pp. 284-302.

Crate, Susan and Nuttall, Mark (2009) Athropology and Climate Change: From Encounters to Actions. Walnut Grove CA: Left Coast Press

Crook, Marnie. Whitefield, TW Allan. Jackson Simon (2009) The commodification of H2O: how water became a designed product, Swimburne Research Bank, Swinburne University of Technology and RMIT University, Melbourne 
De Molina Manuel González, and Toledo, Víctor M (2014) The Social Metabolism. Environmental History 3. Switzerland: Springer International Publishing

Den Hond, Frank and de Bakker G.A., Frank (2007) Ideologically motivated activism: how activist groups influence corporate social change activities. Academy of Management Review 32(3), pp. 901-924.

Descola Philippe Pálsson Gissli (ed) (2005) Introduction. In: Nature and Society: Anthropological Perspectives. London: Routledge, 01-21.

Dibley, Ben (2012) 'The shape of things to come': Seven theses on the Anthropocene and attachment. Australian Humanities Review 52, pp. 139-153.

Doria, Miguel F. (2006) Bottled water versus tap water: understanding consumers» preferences. Journal of Water and Health, 4(2), pp.271-276.

Doria, Miguel F. (2010). Factors influencing public perception of drinking water quality. Water Policy 12(1), pp. 1-19

Dietz, Thomas Ostrom, Elinor and Stern, Paul C. (2003). The Struggle to Govern the Commons. Science 302(5652), pp. 1907-1912

Dryzek, John S., Norgaard Richard B. Schlosberg David (2011) Climate Change and Society: Approaches and Responses. In: Dryzek John S, Schlosberg David (eds) The Oxford Handbook of Climate Change and Society: Oxford University Press, 490-503

Durkheim, Émile \& Steven Lukes (1982) The rules of sociological method. New York: The Free Press

Fauchal, Per Hausner, Vera Helene Schmidt, Jennifer Irene and Douglas, Clark A. (2017). Transitions of social-ecological subsistence systems in the Arctic. International Journal of the Commons, 11(1), pp. 275-329.

Fiske, Shirley Susan Crate, Carole Crumley, Kathy Galvin, Heather Lazrus, George Luber, Lisa Lucero, Tony Oliver-Smith, Ben Orlove, Sarah Strauss, Richard Wilk (2014) Changing the Atmosphere. Anthropology and Climate Change. Final report of the AAA Global Climate Change Task Force, Arlington, VA: American Anthropological Association.

Ferrier, Catherine (2001) Bottled Water: Understanding a Social Phenomenon. Report commissioned by the World Wide Fund for Nature (WWF).

Galbreath Jeremy (2010) Corporate Governance Practices that Address Climate Change: an Exploratory Study. Business Strategy and the Environment 19, pp. 335-350.

Gleick, Peter H. (2004) The Myth and Reality of Bottled Water. In: Gleick Peter H (ed) The World vs Water, The Biennial Report on Freshwater Resources: 20042005. Pacific Institute, Washington D.C., 17-43. 
Gleick, Peter H. Cooley, Heather (2009) Energy Implications of Bottled Water. Pacific Institute, IOP Publishing Environmental Research Letters 4

Harman, Sophie Williams, David (2013) Governing the World? Cases in Global Governance. London: Taylor \& Francis Ltd

Hayward, Tim (2012) Climate change and ethics. Nature Climate Change, 2, pp. 843-848

Hardin, Garrett (1968) The Tragedy of the Commons. Science, 162(3859), pp. 1243-1248.

Jamieson, Dale (2007) When utilitarians should be virtue ethicists. Utilitas 19(2), pp. 160-183.

Johnson, Hope South, Nigel and Walters, Reece (2016) The commodification and exploitation of fresh water: Property, human rights and green criminology. International Journal of Law, Crime and Justice, 44, pp. 46-162.

International Social Science Council (2015) Transformations to Sustainability. [Online, 1 February 2015]. Available at: http:/ / www.worldsocialscience.org. [Accessed 13 October 2016]

Kottak, Conrad P. (1999). The new ecological anthropology. American Anthropologist, 101(1), pp. 23-35.

Koumparou, Dimitra (2002) The communal property: the case study of Radi forest on the island of Icaria. Dissertation, University of the Aegean (in Greek).

Koumparou, Dimitra and Golfinopoulos, Spyros (2016). The Right to Clean and Safe Drinking Water: The Case of Bottled Water. International Journal of Economy, Management and Social Sciences, 5(1), pp. 1-6.

Koumparou, Dimitra (2017). Bottled Water and the Human Right to Water. Proceedings of Sixth International Conference on Environmental Management, Engineering, Planning and Economics (CEMEPE) and SECOTOX, Thessaloniki, Greece, June 25-30, 2017.

Lash, Jonathan and Wellington, Fred (2007) Competitive advantage on a warming planet. Harvard Business Review 85(3), pp. 94-103.

Leyshon, Catherine (2014) Critical issues in social science climate change research. Contemporary Social Science: Journal of the Academy of Social Sciences, 9(4), pp. 359-373.

Lowe, Philip Phillipson, Jeremy and Wilkinson, Katy (2013) Why social scientists should engage with natural scientists. Contemporary Social Science, 8(3), pp. 207-222. 
Milton, Kay (2008) Fear for the Future. The Australian Journal of Anthropology, 19(1), pp. 73-76.

Mol, Arthur P.J. (2001) Globalization and Environmental Reform: The Ecological Modernization of the Global Economy. Cambridge, MA: MIT Press.

Moore Jason W (2014) The End of Cheap Nature. Or How I Learned to Stop Worrying about The Environment and Love the Crisis of Capitalism". In: Suter C, Chase-Dunn C (ed) Structures of the World Political Economy and the Future Global Conflict and Cooperation, Berlin: LIT Verlag, 285-314.

National Research Council (2002) The Drama of the Commons. Committee on the Human Dimensions of Global Change. In Ostrom E, Dietz T, Dolšak N, Stern PC, Stovich S, and Weber E, (eds) Division of Behavioral and Social Sciences and Education. Washington, DC: National Academy Press.

Naustdalslid, Jon (2011) Climate change - the challenge of translating scientific knowledge into action. International Journal of Sustainable Development \& World Ecology 18(3), pp. 243-252.

Manuel-Navarrete, David, Pelling, Mark and Redclift, Michael (2012) Climate change and the crisis of capitalism. In Climate Change and the Crisis of Capitalism: A Chance to Reclaim Self, Society and Nature. Taylor and Francis, 117.

O'Gorman, Maebh, «Global Warming: A Tragedy of the Commons» (2010). Comparative Research in Law \& Political Economy. Research. Paper No. 32/2010.

Ostrom Elinor (1977) Collective Action and the Tragedy of the Commons. In: Hardin G. and Baden J (eds) Managing the Commons. San Fransisco: W. H. Freeman and Company, 173-181

Ostrom Elinor (1992) The Rudiments of a Theory of the Origins, Survival, and Performance of Common Property Institutions. In: Bromley DW (ed) Making the Commons Work. San Francisco, California: ICS Press, 293-318.

Ostrom, Elinor. (1987) Institutional Arrangements for Resolving the Commons Dilemma: Some Contending Approaches. In: McCay BJ, Acheson JM (eds) The Question of the Commons. Tucson: The University of Arizona Press, 250-265.

Ostrom, Elinor. (1990). Governing the Commons: The Evolution of Institutions for Collective Action. , Cambridge: Cambridge University Press

Ostrom, Elinor (2009) A Polycentric Approach for Coping with Climate Change World Bank Policy Research Working Paper no. 5095. [Online, 1 October 2009] Available at: http://www.worldbank.org/external/default/WDSContentServer/IW3P/ 
IB/2009/10/26/000158349_20091026142624/Rendered/PDF/WPS5095.pdf. [accessed 06 May 2010]

Paige, West (2016) An Anthropology for «the Assemblage of the Now». Anthropological Forum, 26(4), pp. 438-445.

Paterson, Matthew and Stripple, Johannes (2007) Singing Climate Change into Existence: On the Territorialization of Climate Policy Making. In: Pettenger M (ed) The Social Construction of Climate Change: Power, Knowledge, norms, Discourses. Hampshire: Ashgate, 149-172.

Peterson, Nicole Broad, Kenneth (2009) Climate and weather discourse in anthropology. From determinism to uncertain futures. In: Susan A. Crate and Mark Nuttal (eds.), Anthropology and climate change. From encounters to actions. Walnut Creek: Left Coast Press, 70-86.

Pacific Institute, (2007) Bottled Water and Energy Fact Sheet, [Online, 1 February 2007] Available at: http://pacinst.org/publication/bottled-waterand-energy-a-fact-sheet. [Accessed 13 November 2014]

Reid, M. Erin and Toffel, W. Michael (2009) Responding to public and private politics: corporate disclosure of climate change strategies. Strategic Management Journal, 30, pp. 1157-1178.

Reuters (2017) EU says China, EU must show joint leadership on climate as U.S. pulls back. [Online, 30 March 2017] Available at http://www.reuters.com/article/us-china-climatechange-euidUSKBN1710FH [accessed 31 March 2017]

Rubin, Edward L. (2016) Rejecting Climate Change: Not Science Denial, but Regulation Phobia. Journal of Land Use and Environmental Law, Forthcoming, Vanderbilt Public Law Research Paper No. 17-3. [Online, 16 January 2017] Available at: https://papers.ssrn.com/sol3/papers.cfm?abstract_id=2900352 [accessed March 31, 2017]

Savenije, Hubert H.G. (2002). Why water is not an ordinary economic good, or why the girl is special. Chemistry of the Earth, 27, pp. 741-744.

Slater, Dashka (2007) Resolved: public corporations shall take us seriously. New York Times Magazine [Online, 12 August 2007] Available at: http://www.nytimes.com/2007/08/12/magazine/12exxon-

t.html?scp=3\&sq=Shareholder

+action\&st=nyt [accessed March 3, 2018]

Stehr, Nico and von Storch, Hans (1995) The social construct of climate and climate change. Climate Research, 5: 99-105. 
Steffen, Will (2015) A truly complex and diabolic policy Problem. In: Dryzek J, Norgaard R, Scholosberg D (eds) The Oxford Handbook of Climate Change and Society. Oxford: Oxford University Press, 21-37.

Sullivan, Rory and Gouldson Andy (2017) The Governance of Corporate Responses to Climate Change: An International Comparison. Business Strategy and the Environment, 26:413-425

Szerszynski, Bronislaw (2016) Viewing the technosphere in an interplanetary light. The Anthropocene Review, 4(2), pp. 92-102.

The Intercept (2017) Donald Trump Is Slashing Programs Linking Climate Change to U.S. National Security. [Online, 26 April 2017] Available at https://theintercept.com/2017/04/26/donald-trump-is-slashing-

programs-linking-climate-change-to-u-s-national-security. [accessed 31 May 2017].

Toivanen, T. Lummaa, K. Majava, A. Järvensivu, P. Lähde, V. Vaden, T. and Eronen, J.T. (2017) The many Anthropocenes: A transdisciplinary challenge for the Anthropocene research. The Anthropocene Review, 4(3), pp. 183-198.

Trentmann, Frank and Taylor Vanessa (2005) From users to consumers: water politics in nineteenth century. London: Birkbecke Prints,

Urry, John (2015) Climate Change and Society. In: Mitchie J, Cooper CL (ed.) Why the Social Sciences Matter. London: Palgrave Macmillan, 45-59.

Ward, Lorna A. Cain, Owen L. Mullally, Ryan A. Holliday, Kathrine S. Wernham, Aaron G.H. Baillie, Paul D. Greenfield, Sheila M. (2009). Health benefits about bottled water: A qualitative study. BMC Public Health, 9, pp. 19.

Whitington, Jerome (2016) What climate change demand of anthropology. Political and Legal Anthropology Review, 39(1), pp. 7-15.

Wilk, Richard (2006) Bottled Water: The pure commodity in the age of branding. Journal of Consumer Culture, 6(3), 303-325.

Wilk, Richard (2011) Water Magic. In Hans Peter Hahn, Karlheinz Cless, and Jens Soentgen (eds.) People at the Well:. Usages and Meanings of Water in a Global Perspective. Chicago: University of Chicago Press, 217-228.

Wilk, Richard (2017) Without Consumer Culture, there is no Environmental Crisis, Cyberseminar on Culture, Beliefs and the Environment 15 - 19 May 2017

Wissenburg, Marcel 2016. The Anthropocene, Megalomania, and the Body Ecologic, in P.H. Pattberg \& F. Zeli (eds) Environmental Governance in the Anthropocene: Institutions and Legitimacy in a Complex World. London: Routledge, 15-30. 
The Governance of the Sociogenic Climate, Koumparou 